JPE (Jurnal Pendidikan Edutama) Vol. 8 No. 1 Januari 2021

P-ISSN : 2339-2258 (Print) E-ISSN: 2548-821X (Online)

http://ejurnal.ikippgribojonegoro.ac.id/index.php/JPE

\title{
AN ANALYSIS OF STUDENTS' PERCEPTIONS IN IMPLEMENTATION 2013 CURRICULUM ON SENIOR HIGH SCHOOL ENGLISH LANGUAGE TEACHING (ELT) IN BOJONEGORO
}

\author{
Mohammad Fatoni ${ }^{1)}$ Moh. Zainuddin ${ }^{2)}$ \\ ${ }^{1}$ Faculty of Teacher Training and Education, Universitas Nahdlatul Ulama Sunan Giri \\ ${ }^{2}$ Faculty of Teacher Training and Education, Universitas Nahdlatul Ulama Sunan Giri \\ Email: mohammadfatoni@ unugiri.ac.id ${ }^{1)}$ zainuddin@ unugiri.ac.id $^{2}$ )
}

\begin{abstract}
This study aims to analyze students' perception in implementation of the 2013 curriculum on senior high school English language teaching (ELT) in Bojonegoro in (1) How are the students' perceptions of the 2013 curriculum in terms of the learning process senior high school English language teaching?(2) How are the students' perceptions on the 2013 curriculum in terms of learning support in senior high school English language teaching?. Results of the analysis of students' perceptions of the 2013 curriculum in English Language Learning and Teaching in terms of the learning process and learning support, they were answered with a questionnaire. The learning process shows the following results: knowledgeperception (81\%), exploration (84\%), consolidation of learning $(81 \%)$, the formation of attitudes and behavior (84\%), formative assessment (81\%), and learning support as follows: teacher quality (97\%), student quality (90\%) facility quality (68\%). It can be concluded that the students' perceptions about the 2013 curriculum were positive, with the percentage strongly agreeing or very suitable between $76 \%-100 \%$.
\end{abstract}

Keywords: 2013 Curriculum; Students' Perceptions; English Language Teaching (ELT); Qualitative Research

Abstrak: Penelitian ini bertujuan untuk menganalisis persepsi siswa dalam implementasi kurikulum 2013 pada pengajaran bahasa Inggris di sekolah menengah atas (ELT) di Bojonegoro dalam (1) Bagaimana persepsi siswa terhadap kurikulum 2013 ditinjau dari proses pembelajaran pada pembelajaran bahasa Inggris di SMA? (2) Bagaimana persepsi siswa terhadap kurikulum 2013 dalam hal dukungan pembelajaran pada pembelajaran bahasa Inggris di SMA ?. Hasil analisis persepsi siswa terhadap kurikulum 2013 dalam Pembelajaran dan Pengajaran Bahasa Inggris ditinjau dari proses pembelajaran dan penunjang pembelajaran dijawab dengan angket. Proses pembelajaran menunjukkan hasil sebagai berikut: pengetahuan-persepsi (81\%), eksplorasi (84\%), konsolidasi pembelajaran (81\%), pembentukan sikap dan perilaku (84\%), penilaian formatif (81\%) dan dukungan pembelajaran sebagai berikut: kualitas guru (97\%), kualitas siswa (90\%) kualitas fasilitas (68\%). Dapat disimpulkan bahwa persepsi siswa terhadap kurikulum 2013 adalah positif dengan persentase sangat setuju atau sangat sesuai antara $76 \%-100 \%$.

Kata Kunci: Kurikulum 2013; Persepsi Siswa; Pengajaran Bahasa Inggris (ELT); Penelitian kualitatif

\section{INTRODUCTION}

The Minister of Education tries to improve the literacy skills of students in understanding English texts in various ways, one of which is by changing the curriculum. Over time, the Government of 
Indonesia has implemented nine curricula to this day.

The latest implemented curriculum is Curriculum 2013 (K-13). In this curriculum, the teaching and learning process focuses on students and emphasizes cooperative learning. A teacher must not dominate the class and stimulate students to be active and critical in the teaching and learning process (Kemdikbud 2013). Teachers must be able to design classes to interact simultaneously, work with their peers, and solve problems in the teaching and learning process independently.

The 2013 curriculum is designed differently from the previous curriculum. These differences include changes in learning patterns that shift from teachercentered learning to student-centered learning and one-way communication interactions between teachers and students, turning into interactive learning between teachers and students. In delivering material, the use of multimedia is encouraged. In the teaching and learning process, a scientific approach is introduced through five stages: observing, questioning, gathering information, associating, and communicating. There are three aspects of assessment, namely knowledge, skills and attitudes, and spiritual and social attitudes.

However, the implementation of the 2013 curriculum has pros and cons from various sides. Although there are positive reactions from the community, there are also negative ones, including students. Some students argued that the teacher only asked them to present the material being taught without giving much initial knowledge and let them discuss the material presented in an undirected manner. This results in students feeling confused, not reaching the learning indicators appropriately and perceiving the curriculum negatively. This of course made the implementation of the K-13 into controversy.
In fact, initial observations of a group of students in class XI or 11 from two different classes at SMA Plus Ar Rahmat by the interview method showed that $90 \%$ of them knew that they were using the 2013 curriculum. Still, they did not understand what the 2013 curriculum was. Often asked to present material taught in makeshift media, to be asked to actively ask friends who are presenting about new things and be given many assignments afterward without giving much feedback whether the material presented is correct. This cannot be justified. Although learning is student-centered, some of the cores of the 2013 curriculum implementation include interactive learning between teachers and students, the use of multimedia and the use of scientific methods or the scientific approach are not fulfilled. In fact, most of them are still confused about the material that has been studied and they complain about the 2013 curriculum. This is not in accordance with the objectives of the 2013 curriculum. Therefore, research on the analysis of students' perceptions of the implementation of the 2013 curriculum on English language teaching (ELT) SMA in Bojonegoro district needs to be done to get information about its implementation and help the government and schools to solve problems that have been faced so far.

Based on the above research background, the research questions are formulated as follows:

(1) How are the students' perceptions on the 2013 curriculum in terms of the learning process in senior high school English language teaching?

(2) How are the students' perceptions on the 2013 curriculum in terms of learning support in senior high school English language teaching? 


\section{METHOD}

This study's objectives include analyzing the implementation of the 2013 curriculum and analyzing students' perceptions of the 2013 curriculum in terms of the learning process and learning support for high school English in Bojonegoro Regency. Research must be carried out in a setting where the researcher has absolutely no control over the variables to achieve the goal. This is done to provide a more detailed and real picture in answering the research questions. Therefore, a qualitative approach is seen as the right approach for this study, namely an approach in which natural regulation and the absence of intervention or manipulation of variables are required (Wiersma 2015). In this study, the author uses a type of qualitative research called basic qualitative studies or basic interpretive studies because it describes and interprets a phenomenon or process (Ary 2010). It defines it as a form of qualitative research that provides a targeted descriptive account for understanding a phenomenon using data that can be collected in various ways.

In this study, the research subjects were high school students of class XI or 11 who attend school in Bojonegoro district. Sources of data in this study were taken from SMAN 3 Bojonegoro. The reason for taking the data source was because the high school used the scientific approach to learning in the 2013 curriculum and had heterogeneous students. In addition, this SMA is a model school that is used as a benchmark for the quality of education in the Bojonegoro district.

In this study, the researcher was an instrument in data collection. In this study, the authors collected data using triangulation techniques including participant observation, structured interviews, and questionnaires as a basis for obtaining information, analyzing problems, and solving them. In the observation stage, the researcher was directly involved in the process of observing the implementation of the 2013 curriculum, recording using a video recorder and recording essential things in the note field. At the interview stage, the researcher will prepare a list of questions regarding the implementation of the 2013 curriculum at the school. Finally, researchers will create and retrieve data through questionnaires to determine students' perceptions of the 2013 curriculum regarding the learning process and learning support for high school English in Bojonegoro Regency.

At the stage of analyzing the observation data, the researcher will describe the implementation of the 2013 curriculum in English lessons. The researcher reviewed the video recordings and field notes and then described them in narrative form. The interview stage will be analyzed through three steps, including reducing data, presenting data, and drawing conclusions. The interviews' results are shown in descriptive explanations to answer questions about students' perceptions in the implementation of the 2013 curriculum. Finally, the researcher will collect the questionnaires given to students, display the data in tabular form and complete it with a percentage. After that, the percentage will be explained in the form of a description to determine students' perception of the 2013 curriculum in terms of the learning process and learning support for high school English in Bojonegoro Regency.

\section{RESULT AND DISCUSSION Questionnaire Analysis Results}

The questionnaire was distributed to 31 students at SMAN 3 Bojonegoro. The instrument contains 2 questionnaire topics, namely the learning process and learning support. In the learning process questionnaire, there are 20 statements, and 
a learning support questionnaire, there are ten statements in English. The data describes students' perceptions of the 2013 curriculum. To analyze the questionnaire data, the researcher used the percentage formula as follows

$$
\begin{aligned}
& \mathrm{p}=\mathrm{x} 100 \% \\
& \text { Explanation: } \\
& \mathrm{p}=\text { Percentage } \\
& \mathrm{f}=\text { Frequency of Respondents } \\
& \mathrm{n}=\text { Number of Participants } \\
& 100 \%=\text { Constant Value }
\end{aligned}
$$

Table 1 Classification data

\begin{tabular}{|l|l|}
\hline Classification & Percentage \\
\hline Strongly Agree & $76 \%-100 \%$ \\
Agree & $51 \%-75 \%$ \\
Less Disagree & $26 \%-50 \%$ \\
Disagree & $0 \%-25 \%$ \\
\hline
\end{tabular}

The results of the data are as follows:

\section{Results of the Questionnaire on the Learning Process}

Table 2 Numbers for Learning Process

\begin{tabular}{|l|l|l|}
\hline No. & Indikator & Question Number \\
\hline 1 & Preknowledge-Apperception & $1,2,3$ and 4 \\
\hline 2 & Exploration & $5,6,7$ and 8 \\
\hline 3 & Learning Consolidation & $9,10,11$ and 12 \\
\hline 4 & The Establishment of attitude and behavior & $13,14,15$ and 16 \\
\hline 5 & Formative Assessment & $17,18,19$ and 20 \\
\hline
\end{tabular}

Table 3 Preknowledge-Apperception in Learning Process

\begin{tabular}{|l|l|l|l|l|l|l|l|l|}
\hline \multirow{2}{*}{ No. } & \multicolumn{2}{l}{ Strongly Agree } & \multicolumn{2}{l}{ Agree } & \multicolumn{2}{l|}{ Less Disagree } & \multicolumn{2}{l|}{ Disagree } \\
\cline { 2 - 9 } & F & P & F & P & F & P & F & P \\
\hline 1 & 14 & $45 \%$ & 8 & $26 \%$ & 6 & $19 \%$ & 3 & $10 \%$ \\
\hline 2 & 17 & $55 \%$ & 9 & $29 \%$ & 4 & $13 \%$ & 1 & $3 \%$ \\
\hline 3 & 15 & $48 \%$ & 12 & $39 \%$ & 3 & $10 \%$ & 1 & $3 \%$ \\
\hline 4 & 18 & $58 \%$ & 7 & $23 \%$ & 4 & $13 \%$ & 2 & $6 \%$ \\
\hline Mean & 16 & $52 \%$ & 9 & $29 \%$ & 4 & $13 \%$ & 2 & $6 \%$ \\
\hline
\end{tabular}

Based on the table above, the data shows that prior knowledge and perceptions by the sub-indicators of the learning process start with things that are known and understood and students are motivated by teaching materials that are interesting and useful for their lives in the learning process according to the 2013 curriculum with a percentage of $52 \%$ Strongly agree, $29 \%$ agree, $13 \%$ disagree less and 6\% disagree. It can be concluded that students' perceptions of the 2013 curriculum in English Language Learning and Teaching in English learning with pre-knowledge and perception indicators are in accordance with the 2013 curriculum. It can be seen that the 
most chosen percentage strongly agrees $52 \%$ and $29 \%$ agrees by students. This means that $81 \%$ of students stated that knowledge and perception are in accordance with the 2013 curriculum.

Table 4 Exploration in Learning Process

\begin{tabular}{|c|l|c|c|c|c|c|c|c|}
\hline \multirow{2}{*}{ No. } & \multicolumn{2}{|c|}{ Strongly Agree } & \multicolumn{2}{|c|}{ Agree } & \multicolumn{2}{c|}{ Less Disagree } & \multicolumn{2}{c|}{ Disagree } \\
\cline { 2 - 9 } & F & P & F & P & F & P & F & P \\
\hline 5 & 14 & $45 \%$ & 11 & $36 \%$ & 4 & $13 \%$ & 2 & $6 \%$ \\
\hline 6 & 11 & $36 \%$ & 15 & $48 \%$ & 4 & $13 \%$ & 1 & $3 \%$ \\
\hline 7 & 16 & $52 \%$ & 10 & $32 \%$ & 4 & $13 \%$ & 1 & $3 \%$ \\
\hline 8 & 12 & $39 \%$ & 14 & $45 \%$ & 4 & $13 \%$ & 1 & $3 \%$ \\
\hline Mean & 13 & $42 \%$ & 13 & $42 \%$ & 4 & $13 \%$ & 1 & $3 \%$ \\
\hline
\end{tabular}

From the table above, the data shows that exploration with sub-indicators introduces new standard material and basic competencies with the knowledge and competencies of students and links the standard material and new basic competencies that students have in the learning process according to the 2013 curriculum, where the percentage of $42 \%$ strongly agrees. , $42 \%$ agree, $13 \%$ less disagree, and 3\% disagree. It can be concluded that the students' perceptions of the 2013 curriculum in English Language Learning and Teaching in English learning with the exploration of indicators in accordance with the 2013 curriculum. It can be seen that the most chosen percentage strongly agrees and agrees 42\%. This means that $84 \%$ of students stated that exploration in learning was in accordance with the 2013 curriculum.

Table 5 Learning Consolidation in Learning Process

\begin{tabular}{|l|l|l|l|l|l|l|l|l|}
\hline \multirow{2}{*}{ No. } & \multicolumn{2}{|l|}{ Strongly Agree } & \multicolumn{2}{l|}{ Agree } & \multicolumn{2}{l|}{ Less Disagree } & \multicolumn{2}{l|}{ Disagree } \\
\cline { 2 - 9 } & F & P & F & P & F & P & F & P \\
\hline 9 & 13 & $42 \%$ & 11 & $36 \%$ & 4 & $13 \%$ & 3 & $10 \%$ \\
\hline 10 & 16 & $52 \%$ & 10 & $32 \%$ & 4 & $13 \%$ & 1 & $3 \%$ \\
\hline 11 & 11 & $36 \%$ & 13 & $42 \%$ & 6 & $19 \%$ & 1 & $3 \%$ \\
\hline 12 & 11 & $35 \%$ & 15 & $48 \%$ & 4 & $13 \%$ & 1 & $3 \%$ \\
\hline Mean & 13 & $42 \%$ & 12 & $39 \%$ & 5 & $16 \%$ & 1 & $3 \%$ \\
\hline
\end{tabular}

Based on the table above, the data shows that the consolidation of learning with sub-indicators involves students actively in interpretation, understanding new material and competencies as well as associating standard material and involving students actively in the problem-solving process in the learning process according to the 2013 curriculum where the percentage of $42 \%$ is very agree, $39 \%$ agree and $16 \%$ 
disagree less and 3\% disagree. It can be concluded that students' perceptions of the 2013 curriculum in English Language Learning and Teaching in English learning with the learning consolidation indicator are in accordance with the 2013 curriculum. It can be seen that the most chosen percentage strongly agrees for $42 \%$ and agrees $39 \%$. This means that $81 \%$ of students stated that the consolidation of learning was in accordance with the 2013 curriculum.

Table 6 the Establishment of Attitude and Behavior in Learning Process

\begin{tabular}{|c|c|c|c|c|c|c|c|c|}
\hline \multirow{2}{*}{ No. } & \multicolumn{2}{|c|}{ Strongly Agree } & \multicolumn{2}{|c|}{ Agree } & \multicolumn{2}{|c|}{ Less Disagree } & \multicolumn{2}{|c|}{ Disagree } \\
\hline & $\mathbf{F}$ & $\mathbf{P}$ & $\mathbf{F}$ & $\mathbf{P}$ & $\mathbf{F}$ & $\mathbf{P}$ & $\mathbf{F}$ & $\mathbf{P}$ \\
\hline 13 & 14 & $45 \%$ & 11 & $36 \%$ & 6 & $19 \%$ & - & - \\
\hline 14 & 12 & $39 \%$ & 10 & $32 \%$ & 8 & $26 \%$ & 1 & $3 \%$ \\
\hline 15 & 13 & $42 \%$ & 16 & $52 \%$ & 2 & $6 \%$ & - & - \\
\hline 16 & 16 & $52 \%$ & 11 & $36 \%$ & 3 & $9 \%$ & 1 & $3 \%$ \\
\hline Mean & 14 & $45 \%$ & 12 & $39 \%$ & 4 & $13 \%$ & 1 & $3 \%$ \\
\hline
\end{tabular}

Based on the table above, the data shows that the formation of attitudes and behaviors by sub-indicators motivates students to apply the concepts, explanations, competencies, and characters that are learned daily and practice learning directly to create new attitudes, competencies and characters in life. daily based on the material studied in the learning process according to the 2013 curriculum, with a percentage of $45 \%$ strongly agree, $39 \%$ agree, $13 \%$ disagree, and $3 \%$ disagree.
It can be concluded that students' perceptions of the 2013 curriculum in English Language Learning and Teaching in English learning with indicators of attitude and behavior formation are in accordance with the 2013 curriculum. It can be seen that the most chosen percentage strongly agrees for $45 \%$ and agrees $39 \%$. This means that $84 \%$ of students stated that the formation of attitudes and behavior was in accordance with the 2013 curriculum.

Table 7 Formative Assessment in the Learning Process

\begin{tabular}{|c|c|c|c|c|c|c|c|c|}
\hline \multirow{2}{*}{ No. } & \multicolumn{2}{|c|}{ Strongly Agree } & \multicolumn{2}{|c|}{ Agree } & \multicolumn{2}{|c|}{ Less Disagree } & \multicolumn{2}{|c|}{ Disagree } \\
\hline & $\mathbf{F}$ & $\mathbf{P}$ & $\mathbf{F}$ & $\mathbf{P}$ & $\mathbf{F}$ & $\mathbf{P}$ & $\mathbf{F}$ & $\mathbf{P}$ \\
\hline 17 & 17 & $55 \%$ & 8 & $26 \%$ & 6 & $19 \%$ & - & - \\
\hline 18 & 13 & $42 \%$ & 14 & $45 \%$ & 4 & $13 \%$ & - & - \\
\hline 19 & 13 & $42 \%$ & 10 & $32 \%$ & 7 & $23 \%$ & 1 & $3 \%$ \\
\hline 20 & 14 & $45 \%$ & 10 & $32 \%$ & 6 & $19 \%$ & 1 & $3 \%$ \\
\hline Mean & 14 & $45 \%$ & 11 & $36 \%$ & 5 & $16 \%$ & 1 & $3 \%$ \\
\hline
\end{tabular}

From the table above, the data shows that formative assessment with subindicators develops ways of evaluating student learning outcomes and uses learning outcomes to analyze student weaknesses and problems faced by teachers to shape student character and competence in learning. The process is in accordance with the 2013 curriculum, with a percentage of $45 \%$ strongly agree, $36 \%$ agree, $16 \%$ disagree less and $3 \%$ disagree. It can be 
concluded that the students' perceptions about the 2013 curriculum in English Language Learning and Teaching in English learning with formative assessment indicators in accordance with the 2013 with the 2013 curriculum. curriculum. It can be seen that the most chosen percentage strongly agrees $45 \%$ and agrees $36 \%$. This means that $81 \%$ of students stated that the formation of formative assessments was in accordance

\section{Results of Questionnaires about Learning Support}

Table 8 Number of Learning Support

\begin{tabular}{|l|l|l|}
\hline No. & Indicator & Questionnaire number \\
\hline 1 & Quality of Teachers & 1,2 , and 3 \\
\hline 2 & Quality of Students & 4,5, and 6 \\
\hline 3 & Quality of Facilities & $7,8,9$ and 10 \\
\hline
\end{tabular}

Table 9 Quality of Teachers in Learning Support

\begin{tabular}{|c|c|c|c|c|c|c|c|c|}
\hline \multirow[t]{2}{*}{ No. } & \multicolumn{2}{|c|}{ Strongly Agree } & \multicolumn{2}{|c|}{ Agree } & \multicolumn{2}{|c|}{ Less Disagree } & \multicolumn{2}{|c|}{ Disagree } \\
\hline & $\mathbf{F}$ & $\mathbf{P}$ & $\mathbf{F}$ & $\mathbf{P}$ & $\mathbf{F}$ & $\mathbf{P}$ & $\mathbf{F}$ & $\mathbf{P}$ \\
\hline 1 & 14 & $45 \%$ & 17 & $55 \%$ & - & - & - & - \\
\hline 2 & 13 & $42 \%$ & 15 & $48 \%$ & 3 & $10 \%$ & - & - \\
\hline 3 & 16 & $52 \%$ & 15 & $48 \%$ & - & - & & \\
\hline Mean & 14 & $45 \%$ & 16 & $52 \%$ & 1 & $3 \%$ & - & - \\
\hline
\end{tabular}

From the table above, it can be seen that the quality of teachers with sub indicators of the percentage of teacher eligibility and the ratio of students per teacher in supporting learning according to the 2013 curriculum with a percentage of $45 \%$ strongly agree, $52 \%$ agree and 3\% disagree. It can be concluded that students' perceptions of the 2013 curriculum in
English Language Teaching and Teaching in English learning with indicators of teacher quality are in accordance with the 2013 curriculum. It can be seen that the most chosen percentage agrees $52 \%$ and strongly agrees $45 \%$. This means that $97 \%$ of students stated that teachers' quality was in accordance with the 2013 curriculum.

Table 10 Quality of Students in Learning Support

\begin{tabular}{|c|c|c|c|c|c|c|c|c|}
\hline \multirow{2}{*}{ No. } & \multicolumn{2}{|c|}{ Strongly Agree } & \multicolumn{2}{|c|}{ Agree } & \multicolumn{2}{|c|}{ Less Disagree } & \multicolumn{2}{|c|}{ Disagree } \\
\hline & $\mathbf{F}$ & $\mathbf{P}$ & $\mathbf{F}$ & $\mathbf{P}$ & $\mathbf{F}$ & $\mathbf{P}$ & $\mathbf{F}$ & $\mathbf{P}$ \\
\hline 4 & 18 & $58 \%$ & 11 & $35 \%$ & 2 & $7 \%$ & - & - \\
\hline 5 & 19 & $61 \%$ & 11 & $35 \%$ & 1 & $3 \%$ & - & - \\
\hline 6 & 10 & $32 \%$ & 18 & $58 \%$ & 2 & $7 \%$ & 1 & $3 \%$ \\
\hline Mean & 15 & $48 \%$ & 13 & $42 \%$ & 2 & $7 \%$ & 1 & $3 \%$ \\
\hline
\end{tabular}

From the table above, the data shows that the quality of students with sub- indicators for the level of repetition, the final grade, the number of graduates, the 
dropout rate, and the average length of study in supporting learning according to the 2013 curriculum with a percentage of $48 \%$ strongly agree, $42 \%$ agree, $7 \%$ disagree less, and 3\% disagree. It can be concluded that students' perceptions of the 2013 curriculum in English Learning and Teaching in English learning with indicators of student quality are in

Table 11 Quality of Facilities in Learning Support

\begin{tabular}{|l|l|l|l|l|l|l|l|l|}
\hline \multirow{2}{*}{ No. } & \multicolumn{2}{l}{ Strongly Agree } & \multicolumn{2}{l}{ Agree } & \multicolumn{2}{l|}{ Less Disagree } & \multicolumn{2}{l|}{ Disagree } \\
\cline { 2 - 9 } & F & P & F & P & F & P & F & P \\
\hline 7 & 8 & $26 \%$ & 14 & $45 \%$ & 9 & $29 \%$ & - & - \\
\hline 8 & 11 & $36 \%$ & 10 & $32 \%$ & 5 & $16 \%$ & 5 & $16 \%$ \\
\hline 9 & 9 & $29 \%$ & 13 & $42 \%$ & 6 & $19 \%$ & 3 & $10 \%$ \\
\hline 10 & 13 & $42 \%$ & 8 & $26 \%$ & 6 & $19 \%$ & 4 & $13 \%$ \\
\hline Mean & 10 & $32 \%$ & 11 & $36 \%$ & 7 & $22 \%$ & 3 & $10 \%$ \\
\hline
\end{tabular}

Based on the table above, the data shows that the quality of facilities based on the standard sub-indicator percentage of classrooms and schools provides learning support facilities in the learning process in supporting learning according to the 2013 curriculum with a percentage of $32 \%$ strongly agree, $36 \%$ agree, $22 \%$ disagree less, and $10 \%$ disagree. It was concluded that the students' perceptions of the 2013 curriculum in English Language Learning and Teaching in English learning with facilities quality indicators were in accordance with the 2013 curriculum. It can be seen that the most chosen percentage agrees $36 \%$ and strongly agrees $32 \%$. This means that $68 \%$ of students stated that the quality of the facilities was in accordance with the 2013 curriculum.

It is important for the researcher to discuss the answers obtained with the research questions in the background about How do students' perceptions of the 2013 curriculum in English Language Teaching in terms of the English learning process and learning support at SMAN 3 Bojonegoro?. Based on students' perceptions of the 2013 accordance with the 2013 curriculum. It can be seen that there are no students who relearn, almost students stay in school, almost no students fail. , there are no students who drop out of school, and the study time is suitable for students. This means that $90 \%$ of students stated that students' quality was in accordance with the 2013 curriculum. curriculum in English Learning and Teaching in terms of the learning process and learning support, they were answered with a questionnaire. The learning process shows the following results: knowledgeperception (81\%), exploration (84\%), consolidation of learning (81\%), the formation of attitudes and behavior (84\%), formative assessment (81\%), and learning support as follows: teacher quality (97\%), student quality $(90 \%)$ facility quality (68\%). It can be concluded that the students' perceptions about the 2013 curriculum were positive, with the percentage strongly agreeing or very suitable between $76 \%-100 \%$.

The findings of this study are in line with previous research conducted by Fajrianti, et. al. (2014), Bulan and Suryaman (2018), Jusnita and Ismail (2018)

Fajrianti et al. (2014) conducted a study on Analyzing Student Perceptions about the Implementation of the 2013 Curriculum in the English Learning Process. The results showed that the five topics (teachers, English teaching methods, learning support, evaluation, and learning in 
the environment) in the questionnaire had positive perceptions of students. It can be concluded that the 2013 curriculum has a good influence on students in the teaching and learning process.

Subsequent research was carried out by Bulan and Suryaman (2018) regarding implementing the 2013 curriculum in English subjects at Public High Schools in Sleman Regency. The results showed that implementing the 2013 curriculum was well executed in planning and learning processes. Constraints in this study, the administration carried out is very burdensome for teachers and encountered several obstacles in implementing the scientific approach.

Jusnita and Ismail (2018) regarding the Implementation of the 2013 Curriculum in English Lessons at SMP Kota Ternate. The results of this study indicate that teaching English uses the scientific approach. However, the implementation was not in accordance with the planned stage and adjusted the circumstances. This difficulty is due to the lack of training in the 2013 curriculum and the limited media available in schools.

Based on the findings and previous research described above, this study has several similarities, especially regarding the research topic, namely the implementation of the 2013 curriculum. However, for several things, it is different. The first point is that the first previous study has a broad topic and focuses on direct learning methods in the environment and uses realia. While this research is on the learning process (learning process) and learning support facilities (learning support). The second point is that the second and third previous studies lacked detail in explaining the learning process in the scientific approach stage and did not discuss learning support. The third point is about the study participants. The participants of this research were students of SMAN 3 Bojonegoro, especially the second grade

\section{Results of Interview Analysis}

To get more in-depth information, researchers conducted interviews. The subject of this interview was an English teacher at SMAN 3 Bojonegoro. There are ten questions asked on the subject. These criteria consist of the 2013 curriculum, implementation, and the 2013 curriculum in learning English. The results of the interview are presented in the paragraph below.

In the first part, the teacher explains about the 2013 curriculum. According to EL (the initial teacher), the 2013 curriculum is a curriculum that was formed and according to the government according to the current situation. He also added that this curriculum emphasizes students' character to create better students and gives students hope that the 21st century will face. According to EL, the role of the curriculum is significant in the development of education. Therefore, to create better students must have an appropriate curriculum.

In the next section, the teacher explains the differences between the previous curriculum and the 2013 curriculum. According to EL, all curricula have positive and negative impacts. To implement this curriculum, the teacher as the implementer and the student as the object must adapt again and become habituated from the start. He also said that basically all curricula are the same. The most important thing is the teacher's actions, whether the teacher can apply the curriculum or not.

In this section the teacher explains the preparation of the 2013 curriculum. For the 2013 curriculum, EL says that it has many differences from the previous 
curriculum in its practice, especially in its assessment. He also noted that it was not only students who emphasized being more creative, but teachers too. Teachers must draw learning according to the wishes of students in learning activities. Therefore, teachers must increase their assessment and creativity.

In the next section the teacher explains the obstacles to the 2013 curriculum. According to EL, there are no significant obstacles. In this curriculum many revisions are confusing for teachers. He also added that sometimes the 2013 curriculum changes often, which makes it difficult for teachers to adapt again. For this reason, the government must stipulate changes to the 2013 curriculum so that teachers are not confused.

In this section, the teacher explains their perceptions of the obstacles to students in the 2013 curriculum. According to EL, students have not implemented this curriculum. He added, maybe it is too early to implement this curriculum with revisions. This curriculum applies something new, such as $5 \mathrm{M}$ (warning, asking questions, collecting data, associating, and communicating). He also said that maybe it could be applied if it was determined from the start and students were used to thinking critically, analytically, etc. But basically, students tend to be timid, and most of them are recipients. Thus, mentally, students have not been actively involved and have not been ideally applied.

In this section, the teacher explains about learning support or facilities at school. According to EL, the facilities at the school are in accordance with the 2013 curriculum. He added that the 2013 curriculum has been implemented for several years. The number of teachers in these schools is district instructors and curriculum instructors in 2013, so that information is obtained from the first source. Thus, the implementation of the 2013 curriculum has been going on for a long time.

In the next section, the teacher explains English learning and teaching in the 2013 curriculum. According to EL, in this curriculum, English learning and teaching consists of two subjects, namely: compulsory English and complementary English. According to EL, the purpose of additional English intended for literature and mandatory English is to structure English. He also added that there are differences in learning English in Vocational High Schools and Senior High Schools. The goal is that in Vocational High School, the students intend to use English learning practically. However, high school students are more emphasized to become academics and continue their studies to a higher level.

In this section, the teacher explains the time for learning and teaching English in the 2013 curriculum. EL said, to be honest, the time for compulsory English learning in the learning process is not enough. According to EL, mandatory English study time is two hours a week, but complementary English study time is four hours a week. He added, sometimes students have difficulty learning compulsory English. Therefore, he hopes that with this complimentary English, the students can improve their English language skills.

The implementation of the 2013 curriculum has been good. In this curriculum, there are no significant obstacles even though students are still adapting to the scientific approach in the learning process, but it can run well over time. Facilities in schools are in accordance with the 2013 curriculum. In English Teaching and Teaching, compulsory English and additional English in this curriculum are not enough. English is 
required to have two hours a week, and additional English has four hours a week.

\section{CONCLUSION}

Based on students' perceptions of the 2013 curriculum in English Language Learning and Teaching in terms of the learning process and learning support, they were answered with a questionnaire. The learning process shows the following results: knowledge-perception (81\%), exploration (84\%), consolidation of learning (81\%), formation of attitudes and behavior (84\%), formative assessment (81\%) and learning support as follows: teacher quality $(97 \%)$, student quality $(90 \%)$ facility quality (68\%). It can be concluded that the students' perceptions about the 2013 curriculum were positive with the percentage strongly agreeing or very suitable between $76 \%-100 \%$.

\section{REFRENCES}

Ary, et. al. (2010). Introduction to Research in Education. Belmont: Wadsworth Publishing.

Bulan, A.\&Suryaman, M. (2018). "Implementasi Kurikulum 2013 Pada Mata Pelajaran Bahasa Inggris Sekolah Menengah Atas Negeri Di Kabupaten Sleman." UNY.

Fajrianti, D., Yufrizal, H., \& Supriady, D.
(2014).
ANALYZING
STUDENTS'PERCEPTION ON 2013
CURRICULUM
IMPLEMENTATION IN ENGLISH
TEACHING
PROCESS. U-JET, 3(7).

Jusnita, N., \& Ismail, A. (2018). Implementasi Kurikulum 2013 Dalam Pembelajaran Bahasa Inggris Di SMP Kota Ternate. EDUKASI, 16(1).

Kemdikbud. (2013). Pembelajaran Berbasis Kompetensi Mata Pelajaran
Bahasa Inggris Melalui Pendekatan Saintifik. Jakarta: Kementerian Pendidikan dan Kebudayaan.

Wiersma, W. 2015. Research Methods in Education: An Introduction. 6th ed. USA: Allyn and Bacon. 
92 JURNAL PENDIDIKAN EDUTAMA, Vol 8, No1.Januari, 2021 